\title{
СОЦІА
}

DOI: https://doi.org/10.32839/2304-5809/2021-11-99-58

УДК 070:369.5

Онкович А.Д., Кузьма С.O.

Київський національний університет культури і мистецтв

\section{КОМПЕТЕНТНОСТНООРІЄНТОВАНА МАСОВОКОМУНІКАЦІЙНА ДІЯЛЬНІСТЬ БАНКІВСЬКИХ СТРУКТУР ЩОДО ПЕНСІОНЕРІВ}

\begin{abstract}
Анотація. Масові комунікації є особливою формою соціального регулювання, при чому вони можуть виступати в значній кількості форматів: від широких інформаційних кампаній до вузькотаргетованих повідомлень; від банального маніпулювання масами до просвітницької діяльності, в т.ч. щодо реформ чи нових послуг, зокрема в банківській сфері. ЗМК, у такій ситуащії, знаходяться у двозначній ситуації: інтерес у власних прибутках від рекламної діяльності банківських структур (капіталістичний модус) та, з іншого боку, служіння інтересам суспільства, зокрема найнезабезпеченішим його верствам, якими, на жаль, $е$ люди похилого віку (соціалістичний модус). В поданій статті ми спробуємо описати ситуацію на медіаринку щодо рекламно-інформаційної діяльності банківського сегменту України, адресатом якої є пенсіонери. Ключові слова: масові комунікації, пенсія, недержавне пенсійне забезпечення, соціальне страхування, банківський продукт, банківська послуга, депозит.
\end{abstract}

Onkovych Artem, Kuzma Snizhana Kyiv National University of Culture and Arts

\section{COMPETENCE-ORIENTED MASS COMMUNICATION ACTIVITY OF BANKING STRUCTURES FOR PENSIONERS}

Summary. Mass communications are a special form of social regulation, and they can appear in a large number of formats: from broad information campaigns to narrowly targeted messages; from banal manipulation of the masses to educational activities, including on reforms or new services, in particular in the banking sector. ZMK, in this situation, are in an ambiguous situation: interest in their own profits from advertising banking structures (capitalist mode) and, on the other hand, serving the interests of society, in particular the most vulnerable, which, unfortunately, are the elderly (socialist) mode). In this article we will try to describe the situation on the media market for advertising and information activities of the banking segment of Ukraine, which is addressed to retirees. From September 1, 2021, the conditions for the payment of pensions and state assistance are required, as well as pensioners and other recipients of social benefits can be transferred to banking services, except for pensioners over 80, people with disabilities and people in need of permanent care. are persons who provide social assistance to persons who are not entitled to a pension, and assist in the review, can apply for delivery or send them to Ukrposhta or the bank. The main component of the social protection system is pensions. Therefore, the further development of the pension system is a guarantee of social protection. Pension provision is one of the main guarantees of material security of incapable citizens, because for incapable pensioners pension actually becomes the main source of their existence. At the present stage of economic development of Ukraine, the main guarantor of social protection of citizens who have lost their ability to work is the system of state pension provision, in particular the state financial body - the Pension Fund. Many people of retirement age are afraid to entrust their money to anyone, let alone voluntarily place it in a banking institution. The most important thing here is to research the market of banking products and services, as well as to choose various profitable and optimal options. In fact, knowing the product will benefit from its use. Indeed, one of the main reasons why the media cover the lives of retirees, talk about their quality of life, and modernize retirees through the use of bank accounts, Internet banking and ATMs is the changes in the pension reform of September 1, 2021. Through effective communication with retirees, everyone will be able to make their lives easier and better.

Keywords: mass communications, pension, private pension provision, social insurance, banking product, banking service, deposit.

$\Pi^{2}$ остановка проблеми. 31 вересня 2021 року вимагаються умови виплати пенсій та допомоги державі, а також пенсіонерів та інших одержувачів соціальних виплат можна переводити на банківські послуги, за винятком пенсіонерів старше 80 років, людей 3 інвалідністю та осіб у необхідність постійного догляду. $\epsilon$ особами, які надають соціальну допомогу особам, які не мають права на пенсію, та допомагають у перегляді, можуть подати заявку на доставку або надіслати їх до Укрпошти чи банку.

Головною складовою системи соціального захисту населення є пенсійне забезпечення. Тому подальший розвиток пенсійної системи є запорукою соціального захисту населення. Пенсійне забезпечення є однією з основних гарантій матеріального забезпечення непрацездатних громадян, оскільки для непрацездатних пенсіонерів пенсія фрактично стає основним джерелом їх існування.

На сучасному етапі економічного розвитку України основним гарантом сощіального захисту громадян, які втратили працездатність, є система державного пенсійного забезпечення, зокрема державний фрінансовий орган - Пенсійний фронд. Багато людей пенсійного віку бояться довірити 
свої гроші кому-небудь, а тим більше добровільно розмістити їх у банківській установі. Тут найважливіше - дослідити ринок банківських продуктів та послуг, а також вибрати різні прибуткові та оптимальні варіанти. Насправді, знання продукту принесе користь від його використання.

Справді, однією із найголовніших причин того, чому ЗМІ висвітлюють життя пенсіонерів, говорять про якість їхнього життя, і осучаснення пенсіонера через користування банківськими рахунками, інтернет-банкінгом та банкоматами - є зміни в пенсійній редрормі від 1 вересня 2021 року. За допомогою едективної комунікації 3 пенсіонерами, кожен зможе зробити їх життя легшим та кращим.

Предметом дослідження виступають механізми використання засобів масової інформації та їх вплив на ПФУ і на пенсійну редорму в цілому.

Метою роботи $є$ детальне вивчення системи пенсійного забезпечення в Україні і тієї ролі, яку відіграє 3МІ для відновлення справедливості при визначенні пенсійних виплат, сучасний стан та перспек-тиви розвитку.

Основні завдання, що необхідно вирішити:

- провести детальне дослідження законодавчої бази, що стосуеться питання пенсійного забезпечення громадян;

- проаналізувати структуру фрінансової системи нашої держави і визначити місце в ній Пенсійного фонду як фрінансового інституту

- проаналізувати механізми надходження dpiнансових ресурсів до Пенсійного фонду;

- охарактеризувати механізми і напрямки використання коштів Пенсійного фонду і згідно завдань, поставлених перед ним;

- дослідити кількість пенсіонерів, які користуються банківськими продуктами і послугами.

- провести оцінку ситуащії, яка склалась у сфрері пенсійного забезпечення, зокрема вичленити ряд недоліків у самій законодавчій базі, що стосуеться даного питання, а також проаналізувати ті фрактори макроекономічного характеру, що мають безпосередній вплив на формування коштів Пенсійного фонду та на формування системи пенсійного забезпечення в нашій державі взагалі;

- проаналізувати основні риси впровадження пенсійної редорми в Україні;

- узагальнити результати дослідження у вигляді висновків.

Аналізом та проблемам останніх досліджень і публікацій, пов'язаним із освітнім аспектом пенсіонерів в сорері банківської справи придали досить значну увагу вітчизняні дослідники. В.Д. Базидевич концентрував увагу на місці та ролі державного пенсійного забезпечення у державній фрінансовій системі [6]. Шляхи розвитку недержавного пенсійного забезпечення в умовах України з урахуванням зарубіжного досвіду досліджувалися Лондар С.Л., Науменковою С.В. та ін. [7; 8]. За період існування України як незалежної держави розроблена досить грунтовна законодавча база щодо регулювання питань пенсійного забезпечення [1-4].

Виклад основного матеріалу дослідження. В даний час дослідження масові комунікації стають більш актуальними в системі пенсійного забезпечення. Стали більш активними в Україні руйнівні масові впливи, такі як: сукупність російської пропаганда, активізація сепаратистських дій на сході України, використання російськими пропагандистами релігійно-національних чинників задля розколу українського суспільства і розпалювання ненависті один до одного), що ставлять учасників процесу в незручне становище, вони втрачають надію на краще майбутне, потрапляючи до маніпулятивного впливу на масову свідомість. В такий непростий час довіру можуть повернути:

- використання «лідерів думок», що передбачає вплив на людину, які виходять безпосередньо із 3MI, і через важливих для учасників авторитетних людей. Неформальне особисте спілкування є значущим для людей, як і "офіційні" ЗМІ;

- публічні заяви, виступи, які опираються на запровадження нових законопроектів для реформування пенсійної системи;

- всілякі засоби поширення ідей, публікації в ЗМI, копії статей;

- поширення індрормації через офріційні сторінки соціальних мереж.

Більшість людей вважає, що сощіальні мережі не популярні серед літніх людей. Але це неправда. В останні роки більше людей похилого віку звертаються до соціальних мереж, ніж будь-яка інша вікова група, що доводить, що ця технологія має великі переваги і для старших вікових груп. Літні люди, які використовують соціальні медіа, отримують багато позитивних прикладів, пов'язаних 3 їх особистим і соціальним життям, оскільки вони більше займаються конструктивною діяльністю та зосереджуються на саморозвитку і прозоро розуміють, в якому напрямку рухається їхне майбутне. Крім того, вони залишаються в курсі останніх новин і тенденцій, і йдуть в ногу з часом.

Але для людей похилого віку це іноді може бути складним, оскільки вони стають слабкими 3 віком і не можуть багато бродити. Однак сьогодні це не викликає занепокоєння, оскільки онлайн-оплата комунальних послуг, мобільного рахунку, а чи навіть якогось товару чи послуги значно полегшили роботу, тому більшість 3 них переходить на отримання пенсій саме на картковий рахунок. Людям похилого віку дуже вигідно замовляти будь-що в Інтернеті та отримувати доставку додому. Все, що вони хочуть, знаходиться лише одним клацанням миші, i їм більше не потрібно виходити чи їздити. Вони також можуть скористатися вигідними пропозиціями щодо онлайн-продажів і навіть отримати купони на знижку для подальшої економії грошей.

У багатьох медіа зараз говорять про фінансову грамотність, як про важливу складову сучасної людини. $\mathrm{E}$ вагомі причини, чому потрібно розглядати такий сучасний варіант, як вклад. Розглянемо переваги на прикладі банківського депозиту:

1. Гроші будуть цілодобово охоронятися в охоронній кімнаті, ніхто не зможе потрапити до них, крім вкладника. Питання безпеки стоїть дуже гостро. Якщо ви зберігаєте свої заощадження в трилітровій банці або під матрацом, завжди буде ризик втратити ці гроші через злодіїв, пожеж та інших непередбачених ситуащій. Влада в банку - найбезпечніший варіант, який збереже нерви та гроші пенсіонерів. 
2. За зберігання грошей на депозиті нараховуватимуться відсотки. Це, безумовно, буде дуже приемним і не зайвим бонусом для пенсіонерів.

3. Страхування ваших інвестицій. Є Фонд гарантування вкладів. Навіть у разі, якщо банк раптово збанкрутуе, вкладник до пенсії до 200 тисяч гривень повертається вкладнику.

4. Місцезнаходження банку. Для старших людей питання розміщення банку ближче до їхнього дому відіграе чи не найважливішу роль. Багатьом пенсіонерам важко потрапити в інший кінець міста, щоб внести або зняти гроші.

Сьогодні йти в ногу з часом вигідно і комфортно як і молодим, так і старшому поколінню. Українська банківська система активно розвивае системи, цільовою аудиторією якої є пенсіонери. Людям пенсійного віку пропонуються спеціальні пропозиції, умови, найбільш вигідні депозити.

Депозити для пенсіонерів, як правило, доступні людям, що мають пенсійне посвідчення. Левова частина пенсіонерів-чоловіків, які відпрацювали за свое життя той стаж, який підходить для отримання пенсійного посвідчення, проте не проходять по пенсійному віку, а він в Україні в порівнянні з жінками-пенсіонерками на 6 років більший. Внесок на депозит для людей похилого віку передбачае той факт, що їх дохід не досить високий, тому спеціальні пропозиціі та акції повинні нести соціальний характер.

Що стосуеться заощаджень, які люди пенсійного віку різними способами намагалися зберегти і не втратити, заробити важкою працею у різні політичні зміни держави, то важливість перевірки умов банку з приводу депозитних ставок ставить це на перше місце. Крім того, вона передбачає вивчення інформації про депозити і від того, наскільки уважно вона вивчена залежить правильність вибору банку. Серед пунктів, які варто уважно врахувати при виборі депозиту:

- відсутність або наявність функції пролонгації депозиту;

- чи відсотки виплачуються щомісячно, а чи капіталізуються;

- хто виплачуе податок на доходи фрізичних осіб та військовий збір: сам пенсіонер чи держава;

- який функціонал депозиту, чи можна його поповнювати, знімати за власним бажанням;

- чи має банк право змінювати умови прописані в договорі та знижувати розмір процентної ставки на свій розсуд;

- яким буде розмір втрат, якщо довгостроковий договір буде розірвано.

Краще заздалегідь дізнатися такі тонкощі і вибрати банк з прозорими, зрозумілими умовами.

\section{Відмінності звичайних депозитів} від депозитів для пенсіонерів

Депозити для пенсіонерів, як правило, відрізняються від звичайних депозитів:

1. Відсоток прибутковості більш вигідний.

2. Максимально зручні умови для користування депозитом і більш розширений функціонал (можливість поповнення, зняття; довгострокове розірвання договору, часткове зняття).

3. Мінімальні внески на депозит, від 100 грн.

Такі відмінності роблять депозити для пенсіонерів вигідними і вселяють довіру. Пенсіонери зможуть розраховувати на додатковий дохід, який підвищить їхню якість життя. Мета бан- ку - захистити майно і вкладення, а не обдурити вкладників. Високі коефіцієнти, які досягають свого максимального ліміту - це ще один плюс в скарбничку переваг депозиту. При виборі банку потрібно також розуміти, що надто виковий відсоток дохідності - не говорить про його надійність, можливо банк шукае так звані «швидкі гроші» для запобігання банкрутства, і їхній фрінансовий результат не в найкращому стані.

Один із найбільших побоювань і частих страхів пенсіонерів - це страх, що коли вони помруть, банк «обов'язково» присвоїть собі їх вкладення, і ніхто з спадкоемщів не зможе зняти ці кошти, тут також потрібно врахувати Закон України № 1709 від 20.10.2014 про спадкове майно, що право на вклад входить до складу спадщини незалежно від способу розпорядження ним і його можна отримати після 6 місяців після смерті, коли вступить майно в спадщину. Тому варто тут розвіяти цей страх. Зазвичай, банк надає пенсіонерам послугу зі складання заповіту на випадок смерті або послугу з оформлення довіреності для розпорядження особистим рахунком. Таку довіреність потрібно завірити у нотаріуса у вибраному банку в присутності вкладника. Згідно з заповітом, у ньому вказуються спадкоемці, які у разі смерті вкладника отримають заощадження. Для того, щоб розпорядитися грошима потрібно надати банку свідоцтво про право на спадщину. Можна також пред'явити дозвіл суду або нотаріуса на те, щоб отримати весь депозит або його частину (і відсотки по ньому).

Також не варто побоюватися “згоряння" вкладень. Тут знову діе Фонд гарантування вкладів, який поверне до 200 тисяч гривень у разі банкрутства банку.

Нині майже 3,5 млн пенсіонерів отримують пенсію через Укрпошту. А Міністерство соціальної політики та Пенсійний фонд України хочуть перевести максимальну кількість пенсіонерів на обслуговування у банки. Тоді в Укрпошті отримуватимуть виплати лише приблизно 1 млн пенсіонерів декількох категорій.

Постає питання: чи зможуть ці 2,5 млн людей легко перейти на обслуговування у банки і чи це буде просто. Люди завжди 3 недовірою ставляться до змін. Тим паче якщо вони існують тільки на папері. Не таємниця, що в українських селах - ні доpiг, ні банків, ні банкоматів. Не кажучи вже про те, що такі нововведення для стареньких мають бути підготовленими і супроводжуватися відповідною інформаційно-роз'яснювальною кампаніею.

Згідно законопроекту про зміну виплат пенсій 3 нового року доведеться опанувати банкомат i навчитися знімати гроші з картки. Саме тут і постае ключове питання навчанню пенсіонерів банківської системи, роль кожного менеджера 3 обслуговування фізичних осіб. Плюси банківського обслуговування для людей поважного віку (особливо тих, хто проживае у сільській місцевості) насправді перетворюються на великі проблеми. Саме тому в ідеальному варіанті проводити навчання мешканцям міст і населених пунктів, де $е$ банкомати, в тому числі й засобами медіа.

На даний момент здаеться так, що швидкий перехід «на картки» спричинить більше складнощів, ніж зручностей, а ще враховуючи пандемію, становить навіть ризик для здоров'я, коли по- 
трібно автобусом, де $є$ велике скупчення людей, дістатися до найближчого населеного пункту, бо більшість пенсіонерів мешкає в селах та невеликих містечках, де або взагалі немає відділень банків, або вони нещодавно закрилися.

До того ж неможливо самостійно зняти кошти в будь-який момент. Потрібно раз на місяць їхати до найближчого банкомата (добре, якщо в межах одного населеного пункту, часто - в інший), додатково витратити гроші на проїзд або просити зняти кошти родичів чи знайомих. I добре, якщо в тому банкоматі ще будуть кошти. А, може, доведеться приїхати ще раз.

Ще необхідно не тільки оформити картку, а й періодично проходити обов'язкову ідентифікацію у банку. I це неповний перелік проблем, 3 якими стикатимуться пенсіонери.

Зважаючи на те, що поштові відділення знаходяться майже у кожному населеному пункті, а листоноші обслуговують мешканців усіх без винятку сіл, селищ, хуторів (навіть найвіддаленіших), можливості пошти доставити та виплатити пенсію значно вищі, ніж у будь-якого банку. Нині зі ста сіл та смт банківські відділення та банкомати є лише в чотирьох. Але і ця статистика погіршується. Лише за останні п'ять років банківська мережа зменшилася на $40 \%$. Тільки упродовж 2020 року кількість банківських відділень скоротилася майже на 870 одиниць, а вся банківська система налічуе лише 7134 відділення. Натомість Укрпошта зберегла мережу 3 майже 11000 відділень. Дані знаходяться на офріційному сайті Міністерство інфраструктури України [10]

Та найголовніше - похилий вік, наявність захворювань (чи інвалідності) часто роблять процес отримання пенсії надзвичайно складним навіть поза межами власного дому, а послуги листоноші - не просто зручними й корисними, а й вкрай необхідними. Адже листоноша не тільки принесе свіжі газети та кошти додому, а й прийме оплату за комунальні послуги, може продати за соціальними цінами товари першої необхідності.

Тому, коли останнім часом так активно обговорюеться питання переходу на банківське обслуговування, потрібно розуміти, що ця реформа зачепить не лише Укрпошту, а й видавничу сdpeру. Тому можновладцям ще раз варто ретельно подивитися на всі аспекти ситуації і знайти таке рішення, яке б враховувало інтереси всіх.

Пенсіонер сам обирає місце отримання пенсії - у відділенні Укрпошти (доставить листоноша) чи у банку на платіжну картку. Як встановлено нормативно-правовими актами, що регулюють виплату та доставку пенсій, виплата пенсії може проводитись підприемствами поштового зв'язку або банківськими установами. Отже, особисто сам пенсіонер визначає, де і як отримуватиме належну йому пенсію. Для цього він має написати власноруч відповідну заяву та надати її до найближчого відділення Пенсійного фонду України. Тобто коли пенсіонеру кажуть, що йому пенсію тепер перераховуватиме банк на картку, а не Укрпошта, це є порушенням його прав.

Ніхто без письмової згоди пенсіонера цього робити не може. Тож якщо ви виходите на пенсію й хочете отримувати гроші вдома від листоноші або уже отримуєте кошти на банківській раху- нок, але хочете перейти на обслуговування в Укрпошту, потрібно зробити декілька простих кроків:

- заповнити заяву на отримання пенсії в Укрпошті;

- підготувати копії документів, які потрібно додати до заяви;

- надати пакет документів до найближчого відділення Пенсійного фонду України,

- отримати пенсію у відділенні або вдома від листоноші. Про це повідомляеться в змінах виплат пенсій на сайті Міністерства індрраструктури [10].

Нагадаємо, що у період дії карантину, який встановлено на рівні держави через поширення коронавірусної інфекції, змінено порядок виплати пенсії та соціальної допомоги.

В країні, де банки і банкомати присутні в $4 \%$ населених пунктів і часто найближчий на відстані в 50-60 км. А як щодо ситуації з корона вірусною кризою, коли транспорт до банку нормально не ходить.

Не є новиною те, що в Україні недостатньо розвинута банківська інфраструктура. По статистиці 37\% українців та 3,5 мільйона пенсіо-нерів не використовують картки. Банків, де мешкає 13 мільйонів громадян - немає (див. табл. 1).

Таблиця 1

Група населених пунктів за кількістю мешканців

\begin{tabular}{|c|c|c|}
\hline $\begin{array}{c}\text { Група населених } \\
\text { пунктів за } \\
\text { кількістю } \\
\text { мешканців }\end{array}$ & $\begin{array}{c}\text { Кількість } \\
\text { населених } \\
\text { пунктів }\end{array}$ & $\begin{array}{c}\text { Кількість } \\
\text { мешканців }\end{array}$ \\
\hline$<100$ & 7667 & 309722 \\
\hline $101-500$ & 10800 & 2842148 \\
\hline $501-1200$ & 6171 & 4627060 \\
\hline $1201-2000$ & 1653 & 2490472 \\
\hline $2000-5000$ & 1113 & 3578029 \\
\hline Усього: & 27404 & 13847431 \\
\hline
\end{tabular}

Джерело: розроблено автором за даними статистики Пенсійного фонду України [11]

Тому питання діджиталізації у вигляді навчання пенсіонерів банківськими продуктами i послугами $є$ другорядним, так як гостре питання стоїть в забезпеченні POS-терміналами та банкомати в населених пунктах, де кількість населення менше 100 або в діапазоні 101-500 і т. д. (див. рис. 1). Завдяки забезпеченню цими обладнаннями питання навчання буде більш доступним, адже на практичному досвіді засвоєння відбувається легшим та швидшим.

Скорочення виплат "Укрпошті" доведеться скоротити понад 10 тисяч листонош, а це означає бюджет отримає менше ССВ, ПДФО та буде виплачувати допомогу з безробіття і субсидії звільненим більше, ніж економія на тарифі на доставку пенсій. При цьому сьогодні (навіть якщо залишити всіх пенсіонерів у спокої), підвищення тарифу становитиме близько 265 мільйонів гривень до 2021 року. Тільки ЄСВ Укрпошта, після підвищення мінімальної заробітної плати до 6000 гривень, сплатить до бюджету на 272 мільйони більше, ніж у 2020 році, не рахуючи +208 мільйонів ПДФО, 55+ мільйонів дивідендів та інших податків. Компанія також плануе підвищити тарифр на доставку пенсій в 2022 році на $11 \%$. 


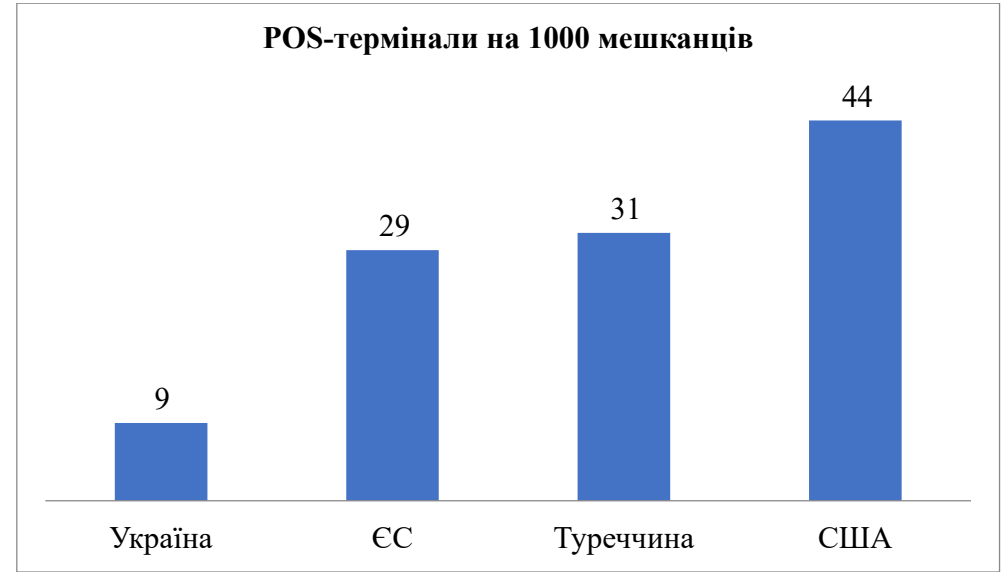

Рис. 1. Кількість POS-терміналів на 1000 мешканців

Джерело: розроблено автором за данили статистики Пенсійного фбонду України [11]

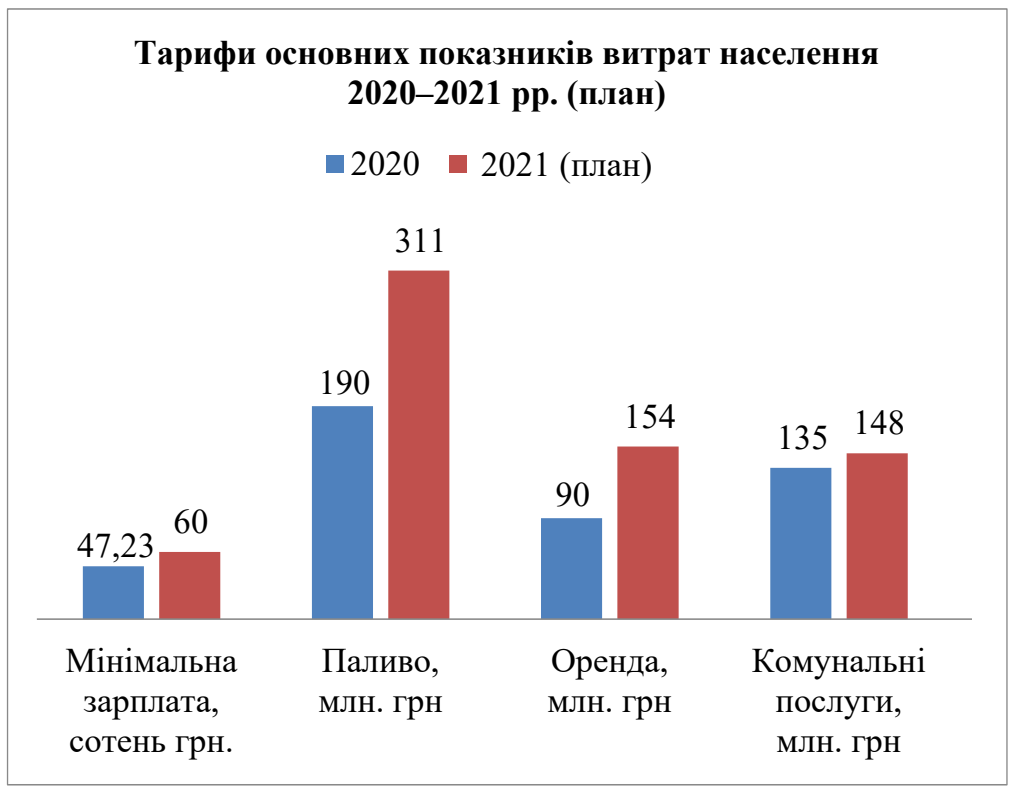

Рис. 2. Тарифи основних показників витрат населення 2020-2021 рр. (план)

Джерело: розроблено автором за даними статистики Пенсійного фонду Украйни [11]

Враховуючи дані показники, можем стверджувати, що навантаження на мінімальну пенсію також зросте, у зв'язку з підвищенням мінімальної зарплати, зростають ціни на паливо, оренду та комунальні послуги. Тому підвищення якості життя соціально незахищене населення пенсіонерів стає ще більш актуальним.

Висновки. Отже, спроби впровадження пенсійної реформи в Україні робляться протягом останніх 25 років. Однак результат не втішає. Працюючі українці не мають стимулів сплачувати пенсійні внески; існуе хронічний дефріцит
Пенсійного фонду, який тисне на державний бюджет; водночас сума, яку Україна витрачае на пенсії, $е$ чи не найбільшою у світі (у відсотках від ВВП), і донедавна мала дуже високі «податки на працю", що заохочувало мотивацію бізнесу йти у тінь. Реформи важко провести через багато об’єктивних та суб'єктивних факторів, включаючи складну демографрічну ситуацію, високий рівень залучення через тіньову економіку, дисбаланс у бюджеті. Після завершення Револющії гідності ми спостерігаємо нову хвилю спроб удосконалити існуючу пенсійну реформу.

\section{Список літератури:}

1. К Конституція України від 28.06.1996. URL:https://zakon.rada.gov.ua/laws/show/254\%D0\%BA/96-\%D0\%B2\%D1\%80

2. Закон України про заходи щодо законодавчого забезпечення реформування пенсійної від 08 липня 2011 р. URL: http://zakon2.rada.gov.ua/laws/show/3668-17/page5

3. Закон України про пенсійне забезпечення від 05 листопада 1991 p. URL: http://zakon4.rada.gov.ua/laws/ show/1788-12/page3

4. Закон України про загальнообов'язкове державне пенсійне страхування від 09 липня 2003 р. URL: http://zakon2.rada.gov.ua/laws/show/1058-15

5. Закон України про недержавне пенсійне забезпечення. URL: http:// zakon1.rada.gov.ua 
6. Закон України про Державний бюджет України на 2020 рік. URL: https://zakon.rada.gov.ua/laws/show/294-IX

7. Базилевич В.Д., Баластрик Л.О. Державні фінанси. 2002. 368 с.

8. Лондар С.Л. Перспективи розвитку недержавного пенсійного забезпечення в Україні. 2011. С. $45-58$.

9. Науменкова С.В. Недержавне пенсійне забезпечення в Україні. 2010. 16 с.

10. Укрпошта загальна інфрормація. 2021. URL: https://mtu.gov.ua/content/ukrposhta-zagalna-informaciya.html

11. Статистика пенсійного фонду України. 2021. URL: https://www.pfu.gov.ua/statystyka/

\section{References:}

1. The Constitution of Ukraine of June 28, 1996. Available at: https://zakon.rada.gov.ua/laws/show/254\%D0\%BA/ $96-\% \mathrm{D} 0 \% \mathrm{~B} 2 \% \mathrm{D} 1 \% 80$

2. Law of Ukraine on Measures for Legislative Support of Pension Reform of July 8, 2011. Available at: http://zakon2.rada.gov.ua/laws/show/3668-17/page5

3. Law of Ukraine on Pension Provision of November 5, 1991. Available at: http://zakon4.rada.gov.ua/laws/show/ 1788-12/page3

4. Law of Ukraine on Compulsory State Pension Insurance of July 9, 2003. Available at: http://zakon2.rada.gov.ua/ laws/show/1058-15

5. Law of Ukraine on private pension provision. Available at: http://zakon1.rada.gov.ua

6. Law of Ukraine on the State Budget of Ukraine for 2020. Available at: https://zakon.rada.gov.ua/laws/show/294-IX

7. Bazilevich V.D., Ballastrick L.O. (2002) Public Finance. 368 p.

8. Londar S.L. (2011) Prospects for the development of private pension provision in Ukraine. P. 45-58.

9. Naumenkova S.V. (2010) Private pension provision in Ukraine. 16 p.

10. Ukrposhta general information (2021). Available at: https://mtu.gov.ua/content/ukrposhta-zagalna-informaciya.html

11. Statistics of the pension fund of Ukraine (2021). Available at: https://www.pfu.gov.ua/statistics 